\title{
REPRESENTASI DAMPAK EKONOMI PANDEMI COVID-19 DALAM FOTO JURNALISTIK DI INSTAGRAM @ REPUBLIKAFOTO (KAJIAN ANALISIS SEMIOTIKA FOTOGRAFI)
}

\author{
Mohammad Solihin ',W. Pandapotan Rambe ${ }^{2}$, Khoirul Umam $^{3}$ \\ 1. Program Studi S-1 Ilmu Komunikasi, Universitas Respati Yogyakarta \\ 2. Program Studi S-1 Ilmu Komunikasi, Universitas Respati Yogyakarta \\ 3. Program Studi S-1 Ilmu Komunikasi, Universitas Respati \\ Yogyakarta mohammadsolihin@respati.ac.id
}
Submitted: 22 Desember 2021| Accepted: 30 Desember 2021 | Published: 31 Desember 2021
Website: https://e-journal.umc.ac.id/index.php/jike/index
DOI: https://doi.org/10.32534/jike.v5i1.2423

\begin{abstract}
One year has a COVID-19 pandemic event hit Indonesia, including countries around the world which has an impact on various sectors of human life. The incident did not escape the record of a photojournalist into the form of photojurnalism published on Instagram @ republikafoto as an account of official reporting Republika photo. Photojournalism as a medium of visual messages from a COVID-19 pandemic event are not fully empty messages without the meaning of the codes or signs made by a photojournalist and the media where they work. The purpose of this study was to find out how the representation of the economic impact of the COVID-19 pandemic in photojournalism in the Instagram account @republikafoto the construction of photojournalists. Using the constructivist paradigm with interpretative descriptive research methods and photo analysis using Roland Barthes photographic semiotic analysis which was fixed on the two-stage significance. The conclusions obtained that one year the economic impact of the COVID19 pandemic that hit Indonesia was not a mere myth, but it was true as the photographs of the journalistic that reported the reality of the fact of the COVID-19 pandemic incident at the the Saung Angklung Udjo traditional cultural performing arts tourist spot, Bandung City, West Java. In denotation the impact represented by the lack of visitors. In connotation illustrates the silence of traditional angklung music performances. And in the myth of the economic impact of the COVID-19 pandemic not only revenue decreases but can still survive with virtual tourism innovations.
\end{abstract}

Keywords: Photography Semiotics, Photojournalism, Roland Barthes, COVID-19 Pandemic, Instagram Account

\begin{abstract}
Abstrak
Satu tahun setelah peristiwa pandemi COVID-19 melanda Indonesia termasuk negara di seluruh dunia yang berdampak pada berbagai sektor kehidupan manusia. Kejadian tersebut tidak luput dalam rekaman seorang jurnalis foto ke dalam bentuk foto jurnalistik yang dimuat di instagram @ republikafoto sebagai akun official pewarta foto Republika. Foto jurnalistik sebagai medium penyampai pesan visual dari sebuah peristiwa pandemi COVID-19 tidaklah sepenuhnya pesan kosong tanpa makna kode-kode atau tanda yang dibuat seorang jurnalis foto dan media di mana mereka bekerja.

Tujuan penulisan ini untuk mengetahui bagaimana representasi dampak ekonomi pandemi COVID-19 dalam foto jurnalistik di akun instagram @republikafoto hasil
\end{abstract}


konstruksi jurnalis foto. Menggunakan paradigma konstruktivis dengan metode penulisan deskriptif interpretatif dan analisa foto menggunakan analisis semiotika fotografi Roland Barthes yang tertuju pada signifikasi dua tahap.

Kesimpulan yang didapatkan bahwa satu tahun dampak ekonomi pandemi COVID-19 yang melanda Indonesia bukan mitos belaka, namun benar adanya sebagaimana foto-foto jurnalistik yang memberitakan realitas fakta kejadian pandemi COVID-19 di tempat wisata pertunjukan seni budaya tradisional Saung Angklung Udjo, Kota Bandung, Jawa Barat. Secara denotasi dampak yang direpresentasikan sepinya pengunjung. Secara konotasi menggambarkan kesunyian pertunjukan musik tradisional angklung. Secara mitos dampak ekonomi pandemi COVID-19 tidak hanya pendapatan menurun namun tetap bisa bertahan dengan inovasi wisata virtual.

KataKunci: Semiotika Fotografi, Foto Jurnalistik, Roland Barthes, Pandemi COVID-19, Akun Instagram

\section{A. Pendahuluan}

Dampak pandemi virus corona atau Corona Virus Disease 2019 diabadikan dalam berbagai karya fotografi dari pewarta foto media massa tidak hanya menggambarkan visual yang indah dan mengharukan namun juga sarat akan berbagai makna. Semenjak kasus positif pertama mencuat di Indonesia setelah diumumkan oleh Presiden Joko Widodo pada 2 Maret 2020 cukup memberikan dampak yang luar biasa dalam satu tahun belakangan ini. Ketakutan dan kepanikan masyarakat akibat yang ditimbulkan oleh virus corona ini tidak hanya karena kasus pertambahan positif COVID-19 di Indonesia yang menurut data Satuan Tugas (Satgas) Penanganan COVID-19 per-1 Maret 2021 menunjukkan 1.341 .314 orang terinfeksi virus corona ini, namun juga tanda-tanda kapan pandemi COVID-19 akan berakhir, belum ada pihak-pihak yang dapat mengetahuinya (cnnindonesia.com, 2021; kompas.com, 2021).

Peta sebaran virus secara global sudah tercatat 120.745.792 kasus yang terkonfirmasi dari berbagai negara (Hopkins, 2021). Tidak hanya menyerang kesehatan, melainkan juga memberikan efek berantai terhadap perekonomian. Bahkan, jumlah pekerja yang terkena Pemutusan Hubungan Kerja (PHK) cukup fantastis akibat virus tersebut juga imbas dari kebijakan pemerintah terhadap Pembatasan Sosial Berskala Besar (PSBB) dan Pemberlakuan Pembatasan Kegiatan Masyarakat (PPKM) Berbasis Mikro untuk memutus mata rantai penyebaran COVID-19. Hal inilah yang membuat aktivitas sosial dan bisnis terhenti sehingga sejumlah besar pelaku bisnis tidak mampu bertahan dan terpaksa mengambil kebijakan merumahkan sebagian bahkan seluruh pekerjanya. Badan Pusat Statistik (BPS) mencatat 29,12 juta penduduk usia kerja atau 14,28 persen terdampak COVID-19 pada Agustus 2020 dan 2,56 juta penduduknya mengalami pengangguran (medcom.id, 2021).

Kasus positif COVID-19 terus bertambah begitu pula dengan korban yang meninggal. Belum lagi dampak ekonomi yang ditimbulkan dengan semakin banyaknya usaha masyarakat yang mengalami penurunan bahkan kebangkrutan dan terjadinya PHK. Peristiwa ini menjadi sorotan utama yang terekam dalam bentuk foto jurnalistik dan melalui medium fotografi inilah menjadi pertanda dunia bahwa begitu seriusnya wabah penyakit ini. Sebagaimana foto kengerian jenazah korban COVID-19 yang terbujur kaku terbungkus plastik dan terbaring di kasur sebuah rumah sakit di Indonesia karya foto jurnalis lepas yaitu Joshua Irwandi untuk majalah National Geographic edisi Agustus 2020 begitu viral dan menjadi perdebatan di dunia maya akan kengerian dampak korban pandemi COVID-19 (kompas.id, 2021a). 
Foto jurnalistik menurut Empu Ageng Fotografi Jurnalistik, Oscar Motuloh, selalu menjadi pendekatan utama sebagai saksi bagi mata dunia untuk berbagai peristiwa yang terjadi, mulai peristiwa gembira, bencana alam, malapetaka, hingga pandemi dalam bentuk selembar foto yang sanggup memenuhi rasa ingin tahu manusia (kompas.id, 2021b).

Karya foto jurnalistik merupakan foto yang bernilai berita. Aspek penting dalam foto jurnalistik adalah unsur fakta, informasi, dan cerita.Anggapan sebuah gambar lebih bermakna dibandingkan seribu kata sudah tidak berlaku. Karena foto jurnalistik membutuhkan keterangan tertulis atau caption (Wijaya, 2018). Sehingga pesan visual dari foto jurnalistik dampak pandemi COVID-19 mampu membangkitkan apa yang tidak terlihat dan memberikan suara kepada mereka yang tidak bisa bersuara.

Sebenarnya foto jurnalistik dibuat dengan tujuan meningkatkan kesadaran masyarakat akan bahayanya COVID-19, menghargai tenaga medis di Indonesia dan di seluruh dunia yang telah bekerja mempertaruhkan hidupnya untuk menolong korban COVID-19 sekaligus mengingatkan untuk tetap tabah dan bersatu menghadapi pandemik ini (Geographic, 2020). Memotret foto jurnalistik wajib memiliki unsur news value yang akan dipublikasikan kepada khalayak.

Salah satu alasan mengapa menjadikan foto jurnalistik menjadi kajian bagi penulis dalam penulisan ini untuk melihat dampak ekonomi pandemi COVID-19 selama satu tahun berlangsung dikarenakan fotografi sebagai wadah untuk memenuhi kebutuhan psikologis dan sebagai media yang memiliki makna dan nilai berita. Disamping itu, foto jurnalistik merupakan medium penyampai pesan visual dalam mereproduksi realitas fakta dari sebuah peristiwa sosial budaya masyarakat tidaklah sepenuhnya pesan kosong tidak bermakna tanpa adanya kode atau tanda dari foto yang dibuat atau dikonstruksi oleh seorang jurnalis foto.

Selain itu, penulis ingin melihat bagaimana representasi dampak ekonomi pandemi COVID-19 yang melanda Indonesia dalam satu tahunan ini oleh jurnalis foto ke dalam foto jurnalistik yang dimuat di akun instagram @ republikafoto. Pemilihan akun instagram @ republikafoto ini merupakan akun official Pewarta Foto Republika dikarenakan instagram dipilih sebagai subyek penulisan dengan pertimbangan bahwa instagram ini merupakan platform media sosial yang paling aktif di Indonesia nomor 4 setelah Youtube, Whatsapp, dan Facebook. Pengguna Instagram di Indonesia tahun 2020 sebanyak 63 juta jiwa dengan prosentase pengguna Instagram berjenis kelamin perempuan: 50,8\% dan pengguna Instagram berjenis kelamin laki-laki: 49,2\% (andi.link, 2020).

Tujuan dari penelitian ini adalah untuk mengetahui bagaimana representasi dampak ekonomi pandemi COVID-19 dalam foto jurnalistik di akun instagram @republikafoto hasil konstruksi jurnalis foto melalui pembacaan semiotika fotografi model Roland Barthes. Menggunakan paradigma konstruktivis dengan metode penelitian deskriptif interpretatif dan analisa foto dikaji dengan teknik analisis semiotika fotografi model Roland Barthes. Foto jurnalistik berjudul "Alunan Sunyi Musik Tradisi" dalam Rana edisi photo story Republika yang dimuat di akun instagram @ republikafoto sebagai sumber data primer. Sedangkan data sekunder dalam penelitian ini dengan cara kepustakaan dan juga internet searching yang telah dikumpulkan sebelumnya untuk melengkapi data primer.

\section{B. TinjauanPustaka}

Penelitian ini membahas terkait foto jurnalistik di instagram @ republikasfoto yang merepresentasikan dampak ekonomi pandemi COVID-19 dengan menggunakan analisis semiotika fotografi. Penelitian ini tidak terlepas dari penelitian-penelitian pada 3 tahun sebelumnya yang memiliki kesamaan ataupun perbedaan pada tema mengenai foto jurnalistik dan pandemi COVID-19 yang diteliti. Pertama, penelitian yang dilakukan oleh Rani Ika Wijayanti dan Mochamad Syaefudin (2020) mengungkapkan foto karya Joshua 
Irwandi yang ia unggah pada akun Instagramnya @joshirwandi menghadirkan jenazah korban dampak dari virus COVID-19 yang dianalisis menggunakan analisis semiotika Roland Barthes. Berbeda dengan penelitian yang penulis lakukan terletak pada foto jurnalistik berbentuk photo story bukan foto tunggal dan mengenai satu tahun dampak sektor ekonomi dari pandemi COVID-19 yang diteliti dengan akun instagram yang juga berbeda, meski topiknya sama tentang pandemi COVID-19 dan analisis semiotik.

Kedua, penelitian oleh Sandi Jaya Saputra (2021) berusaha membongkar makna mitos pada dua foto yang menggambarkan situasi pandemi COVID-19 di Indonesia yang berperan sebagai pintu masuk untuk melihat posisi budaya visual Indonesia dalam menghadapi pandemi COVID-19 dengan menggunakan semiologi Barthesian sebagai pisau analisisnya. Meski sama-sama mengkaji tanda dalam fotografi dan situasi pandemi COVID-19 di Indonesia, namun penelitian ini berbeda dengan yang penulis lakukan yaitu lebih kepada interpretasi dan pembacaan makna dampak ekonomi pandemi COVID-19 yang sudah berlangsung selama satu tahun ke dalam foto jurnalistik.

Sementara ketiga, penelitian oleh Tomi Gunawan dan Silviana Amanda Aurelia Tahalea (2021) lebih kepada bahasan foto yang menggambarkan tentang suasana kehidupan masyarakat Jambi di masa pandemi COVID-19 dalam bentuk fotografi dokumenter hitam putih (black \& white). Penelitian ini tidak menggunakan kajian semiotik untuk pembacaan makna maupun interpretasinya. Sehingga jelas berbeda dengan penelitian yang dilakukan oleh penulis dari sisi foto yang dianalisis adalah foto jurnalistik yang dimuat di akun instagram resmi media pewarta foto dengan menggunakan pisau analisis semiotika fotografi.

\section{Fotografi}

Definisi fotografi dalam KBBI (Kamus Besar Bahasa Indonesia) dari Kementerian Pendidikan dan Kebudayaan, diartikan dengan seni dan penghasilan gambar dan cahaya pada film atau permukaan yang dipekakan (KBBI, 2016). Istilah fotografi dikemukakan pertama kali oleh seorang ilmuwan Inggris, Sir John Herschell pada 14 Maret 1839. Secara terminologi fotografi berasal dari bahasa Yunani yaitu Photos dan Graphos. Photos artinya cahaya dan Graphos artinya menggambar/melukis, maka dapat diartikan secara utuh bahwa fotografi adalah melukis dengan cahaya (Burhanuddin, 2014). Oleh karena itu seni fotografi hanya akan terjadi jika ada unsur cahaya. Tanpa adanya cahaya, maka dipastikan foto yang dibuat tidak akan jadi.

Sebagaimana dalam sejarah awal mula tentang fotografi sejak masa pra fotografi pada abad 16, para astronom memanfaatkan camera obscura untuk merekam konstelasi bintang-bintang secara tepat. Istilah "kamera obscura" diciptakan oleh Johannes Kepler pada tahun 1604 seorang astronom Jerman membuat desain kamera portable yang dibuat dengan ukuran besar seperti sebuah tenda. Didalam tenda sedikit cahaya yang ditangkap oleh lensa karena kondisi sangat gelap, membentuk gambar keadaan di luar tenda di atas selembar kertas. Alat ini kemudian digunakan pula untuk bidang-bidang kegiatan lain, termasuk seni lukis, terutama bagi aliran realisme dan naturalism (Ajidarma, 2002; Burhanuddin, 2014). Hal ini yang mendorong sejumlah penemuan-penemuan teknologi mutakhir fotografi terutama berkaitan dengan pengembangan untuk sarana memperbaiki dan mempertahankan.

Kemajuan teknologi turut memacu perkembangan fotografi dengan begitu sangat cepatnya. Kamera dulu sebesar tenda hanya bisa menghasilkan gambar tidak terlalu tajam, kini kamera digital yang hanya sebesar dompet mampu membuat foto dengan sangat tajam dalam ukuran sebesar koran (Burhanuddin, 2014). Dunia fotografi merupakan dunia kreativitas tanpa batas dimulai dari pemilihan peralatan yang dipakai, kejelian menentukan obyek pemotretan sampai proses pencetakan foto. Fotografi dapat menampilkan sebuah 
kenyataan atau realita dan dalam seni fotografi tidak ada unsur abstrak. Proses visualisasi karya adalah menghidupkan dan memberi jiwa pada karya foto. Seperti halnya dengan seniman seni rupa lainnya, fotografer bekerja menggunakan otak dan hatinya yaitu segala tindakan yang dilakukan, terutama dalam proses pengambilan obyek, ia akan mengetahui hasil yang akan diperoleh sehingga melakukan tindakan-tindakan yang berguna untuk mendukung ide dan gagasannya (e-journal.uajy, 2021). Tidak salah jika foto-foto dapat lebih mudah untuk diingat dibandingkan dengan gambar bergerak. Foto juga lebih dipercaya sebagai testimoni independen, agen diskursus sosial, dan kini mudah dibagikan dalam waktu sekejap ke banyak orang.Untuk dapat menjelaskan bagaimana potret wajah seseorang atau betapa menakutkannya kematian akibat dampak yang ditimbulkan pandemi COVID-19 dan dampak ekonomi yang harus ditanggung oleh masyarakat akibat pandemik ini, maka sebuah foto mampu melakukannya.

\section{Foto Jurnalistik}

Foto jurnalistik merupakan bertemunya fotografi dan jurnalistik. Secara sederhana foto jurnalistik adalah foto yang mempunyai nilai berita dan menarik bagi pembaca.Aspek penting yang harus ada dalam foto jurnalistik adalah unsur fakta, informasi, dan cerita.Anggapan dalam foto jurnalistik bahwa sebuah gambar bermakna dibandingkan seribu kata tidaklah berlaku. Karena foto jurnalistik membutuhkan keterangan tertulis atau teks penyerta (caption) (Wijaya, 2018). Inilah yang membedakan antara foto jurnalistik dengan fotografi lainnya.Caption membantu mengarahkan persepektif sebuah foto dan menjelaskan detail informasi yang tidak ada dalam foto, yang membingungkan, ataupun tidak jelas. Keterangan pada foto untuk mempertemukan foto dengan konteksnya dan membantu pembaca membangun pemahaman cerita dibaliknya, menggiring mata si pembaca untuk kembali melihat foto.

Konsep jurnalistik menggunakan rumus $5 \mathrm{~W}+1 \mathrm{H}$ menjadi batasan yang jelas dalam menilai sebuah foto jurnalistik sebagai bagian dari produk jurnalistik.Foto jurnalistik sebagai media visual merupakan bagian dari suatu cara berbahasa yang menarik suatu makna. Sebuah foto jadinya bukan hanya representasi visual objek yang direproduksi, melainkan mengandung pesan yang bermakna (Ajidarma, 2016).

Alat terbaik saat ini yang mampu menghubungkan manusia di seluruh dunia dengan bahasa gambar yang dapat melaporkan peristiwa umat manusia secara ringkas dan efektif adalah foto jurnalistik.Peristiwa pandemi COVID-19 yang melanda seluruh dunia begitu mudahnya untuk diceritakan melalui foto jurnalistik. Ketakutan, kengerian akan dampak dari COVID-19 ini disajikan dengan detail melalui bidikan pewarta foto yang menghasilkan foto jurnalistik hasil dari realitas dan fakta yang terjadi, bukan hanya menarik mata memandangnya namun juga syarat akan nilai berita yang memiliki makna dalam peristiwa yang disajikannyamenjadi sebuah pengetahuan.

\section{Semiotika}

Istilah semiotik atau semiotika secara etimologis berasal dari kata Yunani semeion atau "tanda". Pemahaman semiotika pada tanda dan cara tanda dipergunakan memperlihatkan adanya kajian akan tanda sebagai objek yang disampaikan. Sehingga dalam kajian semiotika tanda dimaknai terlebih dahulu sebagai upaya pemahaman yang merujuk kepada objek. Pemahaman inilah yang dibutuhkan dalam memahami semiotika dimana tanda sebagai objek dapat mewakili pemahaman sosial sebagai sarana pemahaman semiotika (Sobur, 2015).

Inti fokus semiotika adalah tanda. Semiotika memiliki tiga wilayah studi utama yaitu (Fiske, 2016): 
1. Tanda itu sendiri, karena tanda itu hasil konstruksi manusia, maka hanya bisa dipahami dengan cara manusia menggunakannya.

2. Organisasi kode atau sistem tanda, meliputi cara-cara di mana beragam kode dikembangkan agar dapat memenuhi kebutuhan sebuah masyarakat atau kultur atau untuk mengeksploitasi saluran komunikasi yang tersedia dalam proses transmisi tanda.

3. Kebudayaan tempat kode-kode dan tanda-tanda itu beroperasi untuk eksistensi dan bentuknya sendiri.

Tanda bisa dipersepsi indra manusia karena sesuatu yang bersifat fisik; tanda mengacu pada sesuatu di luar tanda itu sendiri; dan bergantung pada pengamatan oleh penggunanya. Semiotik didefinisikan sebagai ilmu yang mempelajari sederetan luas objekobjek, peristiwa-peristiwa yang terjadi, seluruh kebudayaan, yang diartikan sebagai tanda. Oleh karena itu, antara semiotika dan tanda sangat erat kaitannya, sehingga semiotika lebih dimaknai sebagai ilmu tanda (Sobur, 2015). Tanda dapat berupa apa saja yang maknanya dibuat dan disepakati hingga dapat bermakna berada dalam berbagai interaksi manusia.

Salah satu model semiotika yang digunakan adalah model Roland Barthes. Pandangan Barthes mengenai tanda itu ada dua yakni penanda atau signifieryang mewakili elemen bentuk atau isidan petanda atau signified yang mewakili elemen konsep atau makna. Kesatuan antara penanda dan petanda itulah disebut sebagai tanda yang menjadi mediator antara makna denotasi, makna konotasi dan juga mitos menjadikan tiga bagian inti yang dibangun Barthes dalam signifikansi model dua tahap pemaknaansebagai konsep utama yang membangun tanda (Sobur, 2015). Posisi penanda dan petanda itu sendiri merujuk pada denotasi sekaligus bermakna konotatif yang berada pada pergantian tataran pertama.

\section{Metode Penelitian}

Jenis penelitian ini menggunakan pendekatan kualitatif untuk dapat memaknai representasi dampak ekonomi pandemi COVID-19 dalam foto jurnalistik di instagram $@$ republikafoto. Berbagai persepsi, tindakan, motivasi dan berbagai bentuk cara jurnalis foto merepresentasikan dampak ekonomi pandemi COVID-19 dalam karya foto jurnalistiknya dapat dimaknai dengan mempelajari objek-objek gambar yang diproduksinya. Menggunakan paradigma konstruktivis dengan metode penelitian deskriptif interpretatif dan analisa foto dikaji dengan teknik analisis semiotika fotografi model Roland Barthes. Alasan peneliti menggunakan analisis semiotika fotografinya Roland Barthes dikarenakan objek yang diamati dalam foto jurnalistik pada penelitian ini dimaknai dengan interpretasi makna yang memungkinkan peneliti untuk dapat menginterpretasikan representasi dampak ekonomi pandemi COVID-19 dalam foto jurnalistik yang dibuat jurnalis foto.

Penelitian ini menempatkan foto jurnalistik berjudul "Alunan Sunyi Musik Tradisi" dalam Rana edisi photo story Republika yang dimuat di akun instagram @ republikafoto sebagai sumber data primer menggambarkan adanya upaya interpretasi tekstual jurnalis foto dalam merepresentasikan dampak ekonomi satu tahun pandemi COVID-19 yang dapat dimaknai melalui penggunaan tekstual maupun visual. Sedangkan data sekunder dalam penelitian ini adalah proses pencarian data dengan cara kepustakaan dan juga internet searching yang telah dikumpulkan sebelumnya untuk melengkapi data primer. Data tersebut dapat berupa buku, jurnal, website atau sumber online, dan sumber lainnya yang ada relevansinya dengan penelitian topik ini.

Analisis data digunakan sebagai upaya untuk menjawab dan menjelaskan fenomena 
atau permasalahan yang sedang diteliti atau yang disebut dengan interpretasi data. Setelah data selesai dikelompokkan, kemudian tim menganalisa data primer dan menginterpretasikannya melalui pisau teoritik guna mencari jawaban penelitian sedetail mungkin dan mengaitkannya dengan konteks. Selanjutnya, penulis melakukan display data, di mana setelah serangkaian proses tersebut penulis kemudian menuangkan data dalam bentuk tulisan. Bagian ini menyajikan presentasi naratif maupun visual. Semua data yang terkumpul dianalisis dengan teknik analisis semiotika fotografi Roland Barthes. Kemudian semua data temuan tersebut oleh penulis disimpulkan menjadi temuan tertentu.

\section{Hasil dan Pembahasan}

Terdapat 8 (delapan) foto jurnalistik berjudul "Alunan Sunyi Musik Tradisi” hasil jepretan Abdan Syakura, Pewarta Foto koran Republika yang dibahas oleh penulis merupakan inti dari isi keseluruhan penelitian ini dari pokok permasalahan. Akun instagram @republikafoto yang menjadi tempat memuat foto-foto jurnalistik tersebut merupakan akun official Pewarta Foto koran Republika dengan 1819 follower yang dimiliki. ${ }^{1}$ Selain itu, foto-foto jurnalistik tersebut merupakan foto yang sudah ditayangkan di media online Republika (https://www.republika.co.id/berita/qp8lks375/alunan-sunyimusik-tradisi) dalam sebuah Kanal bernama In Picture.

Narasi berita tersebut (Syakura, 2021) menyebutkan pandemi COVID-19 memaksa semua orang harus tinggal di rumah sehingga memberikan dampak besar bagi perekonomian masyarakat. Sejumlah tempat usaha dan wisata sepi dari pengunjung membuat pemasukan turun drastis dan pengeluaran tetap berjalan. Salah satu yang menjadi obyek foto jurnalistik oleh sang fotografer adalah Saung Angklung Udjo, tempat wisata pertunjukan seni budaya tradisional musik angklung di Kota Bandung, Jawa Barat yang terancam ditutup karena persoalan biaya operasional. Untuk bertahan, pihak pengelola membuat terobosan dengan cara tetap memberikan pelatihan angklung dan memproduksi berbagai jenis angklung serta membuat wisata virtual Saung Angklung Udjo.

Foto jurnalistik yang menjadi temuan penelitian ini kemudian dianalisis dengan tatanan signifikasi dua tahap model Roland Barthes. Siginifikasi tahap pertama menjelaskan hubungan antara signifier (penanda) dan siginified (petanda) yang disebut dengan makna Denotasi atau makna sebenarnya dari tanda. Sedangkan siginifikasi pada tahap kedua menjelaskan makna Konotasi atau makna yang subjektif dan menjelaskan makna Mitos yang berhubungan dengan isi.

Untuk memahami makna konotasi, ada 6 prosedur yang diajukan oleh Barthes dalam pembacaan konotasi citra foto (Budiman, 2003) yaitu: 1) Rekayasa langsung memengaruhi realitas itu sendiri diantaranya Trick Effect atau manipulasi gambar sampai tingkat berlebihan; Pose atau gaya, posisi, ekspresi dan sikap objek foto yang diambil oleh seorang foto jurnalis; Objek atau point of interest (POI) pada sebuah foto. 2) Rekayasa wilayah estetis diantaranya Photogenia atau teknik pemotretan seperti lighting (pencahayaan), exposure (ketajaman foto), bluring (keburaman), panning (efek kecepatan), angle (sudut pandang pengambilan objek), position (posisi pemotretan) dan sebagainya; Aestheticism atau estetika komposisi gambar secara keseluruhan dan dapat menimbulkan makna konotasi; Sintaksis atau rangkaian cerita dari isi foto yang biasanya berada pada caption (keterangan foto) dalam foto berita menimbulkan makna konotasi.

\footnotetext{
${ }^{1}$ Data follower terakhir yang tercatat oleh penulis pertanggal 5 November 2021 pukul 19.35 WIB sebanyak 1.820 followers pada akun Instagram @ republikafoto
} 


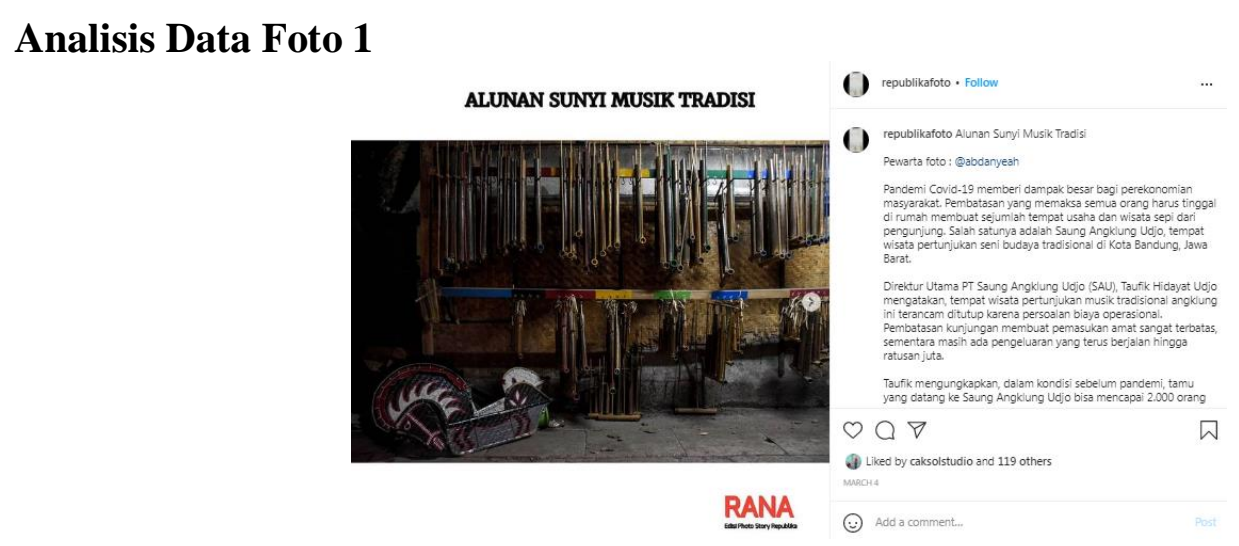

Gambar 1. Data foto 1 dalam tampilan akun Instagram @ republikafoto Sumber: https://www.instagram.com/p/CMAM-BsH5UB/

Tatanan signifikasi pertama pada makna Denotasi yang tampak dalam foto tersebut memperlihatkan deretan alat musik tradisional yaitu angklung dan mainan tradisional jaranan dengan latar belakang atau background anyaman bambu atau gedeg. Tatanan signifikasi kedua makna Konotasi pada a) Trick Effect yakni manipulasi atau rekayasa foto yang pada akhirnya mengubah esensi dari realitas sebuah foto tidak diperbolehkan dalam foto jurnalistik dan dapat mengarah kepada tindakan penyebar kebohongan. Terjadinya rekayasa foto sebenarnya bukan hanya dari sisi edit foto saja, namun bisa juga terjadi pada pemilihan objek oleh fotografer, angle atau sudut pengambilan. Sementara itu pengolahan foto atau editing yang diperkenankan dalam foto jurnalistik sebatas cropping, rotating, dan koreksi warna untuk kecerahan foto. Sehingga dalam foto tersebut yang ditampilkan tidak tampak dan tidak ditemukan adanya manipulasi atau rekayasa foto yang merubah fakta sebenarnya. b). Pose yakni tampilan foto yang ada pada foto tersebut termasuk ke dalam jenis Still Life Photography atau memotret yang objeknya benda-benda mati/ tidak bergerak dengan format foto horizontal. Sehingga peneliti tidak menemukan unsur pose atau gaya ekspresi yang ditampilkan karena pose hanya dapat dilihat pada objek foto yang menampilkan objek hidup seperti manusia, ataupun hewan. c). Object yakni objek yang ditampilkan menjadi point of interest (POI) terlihat menonjol dan menarik mata memandang pada sebuah foto tersebut adalah deretan alat musik tradisional angklung. Sebab Saung Angklung Udjo ini merupakan tempat pertunjukan wisata seni budaya tradisional khas Jawa Barat. d). Photogenia yakni foto yang diambil dengan menggunakan teknik pemotretan diantaranya lighting atau pencahayaan di dalam ruangan (indoor) di mana kondisi minim cahaya dan fotografer menggunakan artificial light atau sumber cahaya buatan yang menurut peneliti dari cahaya lampu pijar yang ada di ruangan tersebut di sebelah kanannya fotografer sehingga kesan yang ditimbulkan dari arah datangnya cahaya di sebelah kiri fotografer (kanannya objek foto) terlihat perbedaan gradasi antara area yang gelap (shadow) dengan area yang terang (highlight) pada objek. Sementara angle atau sudut pandang pemotretan menggunakan low angle yaitu pengambilan dari sudut pandang bawah di mana objek deretan angklung sebagai POI- nya berada lebih tinggi dari fotografer yang memberi kesan ada kemegahan/ kekuatan yang diangkat dan dipertahankan. e). Aestheticism atau estetika foto yang tampak menampilkan deretan angklung baik yang posisi menggantung maupun posisi di bawah dalam komposisi gambar yang lebih dominan dengan format gambar landscape atau horizontal memberikan keleluasaan pandangan terhadap objek utama yang menjadi titik perhatian. Disamping itu juga penempatan mainan tradisional jaranan berada di bawah sebelah kiri memberikan pesan sunyi/ sepi tidak adanya kegiatan yang dapat menghidupkan alat musik tradisional 
tersebut. f). Syntax atau sintaksis dalam sebuah foto jurnalistik biasanya dapat dilihat lewat teks yang ada pada caption atau keterangan foto. Sintaksis pada foto tersebut adalah deretan alat musik tradisional di Saung Angklung Udjo, tempat wisata pertunjukan seni budaya tradisional di Kota Bandung, Jawa Barat.Secara tersirat menggambarkan kesunyian kegiatan alunan musik tradisional akibat pandemi COVID-19.

Makna Konotasi yang dihasilkan dalam foto tersebut setelah melalui tahapan 6 (enam) prosedur pembacaan konotasi citra foto memperlihatkan sebuah bentuk rangkaian pesan yang ingin disampaikan oleh fotografer kepada khalayak bahwa terdapat persoalanpersoalan akibat dampak pandemi COVID-19 yang mendera tempat wisata pertunjukan seni budaya tradisional, Saung Angklung Udjo di Kota Bandung, Jawa Barat. Sedangkan Mitos yang terbangun dalam foto tersebut memiliki tafsir dan makna tentang kejadian pandemi COVID-19 yang sudah berlangsung selama 1 tahun di Indonesia ini memberikan dampak yang signifikan bagi tempat wisata yang memang mengandalkan pengunjung sebagai pemasukan utamanya. Dampak yang terlihat dalam foto tersebut dengan digantungkannya alat-alat musik tradisional angklung dan tergeletaknya mainan tradisional jaranan begitu saja di bawah menandakan tidak adanya kegiatan pertunjukan alunan musik dan mainan tradisional akibat tidak adanya pengunjung yang memenuhi tempat wisata tersebut.

\section{Analisis Data Foto 2}

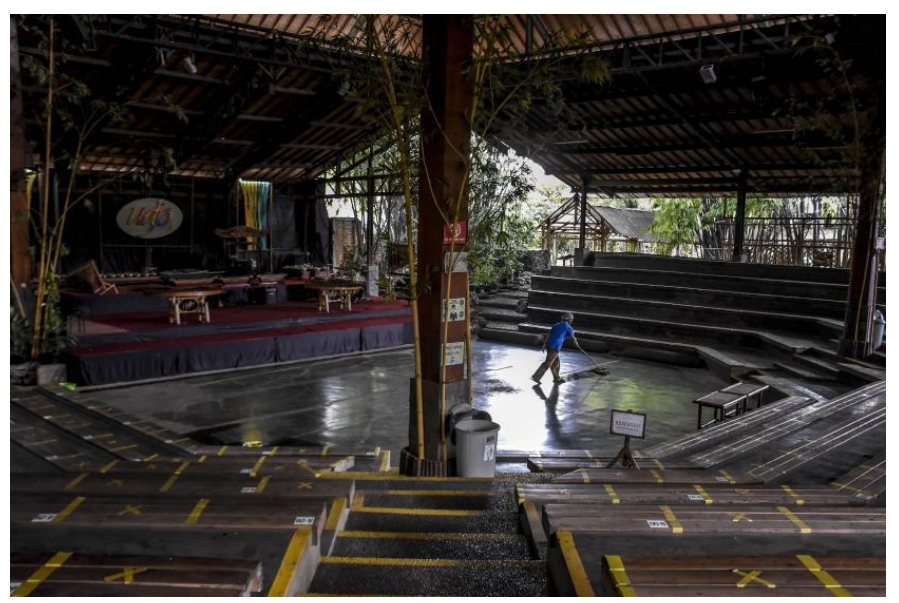

Gambar 2. Data foto 2 dalam akun Instagram @ republikafoto

Tatanan signifikasi pertama pada makna Denotasi tampak dalam foto tersebut memperlihatkan panggung pertunjukan permainan musik ada logo nama UDJO sedang sepi hanya terlihat tempat duduk dengan posisi melengkung mengelilingi panggung yang diberi beberapa tanda silang warna kuning, ada tiang di tengahnya panggung, dan terlihat ada seorang yang sedang membersihkan tempat tersebut memakai baju biru memegang sapu pel di tangannya. Tatanan signifikasi kedua makna Konotasi pada a) Trick Effect atau manipulasi foto berlebihan dalam foto jurnalistik tidak diperbolehkan, sehingga foto tersebut tidak tampak dan tidak ditemukan adanya manipulasi foto, hanya sekadar koreksi warna agar terlihat gradasi gelap terangnya foto tersebut. b) Pose atau tampilan foto yang ada pada foto tersebut memperlihatkan bagaimana keadaan sebuah tempat pertunjukan musik tradisional yang kosong dan ada tanda silang warna kuning pada tempat duduk melingkari panggung utama. Unsur pose atau gaya memperlihatkan seorang laki-laki yang sedang membersihkan tempat tersebut mengarah pada teknik leaving space atau meninggakan ruang kosong yang luas di sekitar subjek yang kosong. c) Object yang ditampilkan menjadi point of interest (POI) terlihat menonjol dan menarik mata 
memandang pada sebuah foto tersebut adalah suasana tempat pertunjukan musik tradisional yang kosong dan beberapa ada tanda silang warna kuning pada tempat duduk melingkari panggung utama. Sementara seorang laki-laki yang terlihat selangkah demi selangkah membersihkan tempat tersebut sebagai pendukung objek utama. Fotografer berusaha membuat yang melihat memahami keadaan yang terjadi saat ini di sana seperti apa dan bagaimana. d) Photogenia menggunakan teknik pemotretan diantaranya lighting atau pencahayaan available light yang memanfaatkan sumber cahaya seadanya di lingkungan sekitar yang dipotret pada saat siang hari, sehingga kesan yang ditimbulkan dari arah datangnya cahaya matahari pada siang hari di area tempat panggung pertunjukan yang terbuka kiri dan kanannya terlihat perbedaan gradasi antara area yang gelap (shadow) dengan area yang terang (highlight) pada objek. Tingkat ketajaman gambar atau Depth Of Field (DOF) pada background dan foreground terlihat merata pada semua sisi objek yang menurut peneliti menggunakan exposure bukaan diafragma (f) kecil pada angka besar bekisar f/8 atau f/11 dengan ASA/ISO bekisar ISO 800 yang nampak sedikit grain pada fotonya dengan shutter speed 1/80 untuk mendapatkan efek freezing atau tidak bergerak pada objek orang yang membersihkan lantai pertunjukan. Sementara angle atau sudut pandang pemotretan menggunakan high angle yaitu pengambilan dari sudut pandang atas di mana objek tempat duduk pertunjukan musik tradisional dengan beberapa tanda silang warna kuning sebagai POI nya berada lebih rendah dari fotografer. Kesan yang diberikan oleh fotografer yang berada pada posisi pemotretan di atas tempat duduk pengunjung yang menonton pertunjukkan menggunakan lensa wide untuk memperlihatkan panggung yang luas terlihat kosong dan lengang tanpa pengunjung karena tidak berdaya dengan adanya pandemi COVID-19. e) Aestheticism tampak memperlihatkan tempat duduk yang melingkar menghadap panggung utama pertunjukan musik tradisional dengan sebuah tiang yang ditempatkan pada posisi di tengah terlihat lengang hanya ada seorang laki-laki yang sedang memegang sapu pel membersihkan tempat tersebut di masa pandemi COVID-19. Tanda silang warna kuning pada tempat duduk untuk mengatur jarak antar pengunjung merupakan tanda adanya protokol kesehatan selama pandemi COVID-19 sebagai titik perhatiannya fotografer dalam membuat komposisi yang menarik.f) Syntax yang ada pada caption foto tersebut adalah tempat pementasan utama Saung Angklung Udjo terlihat lengang. Tersirat menggambarkan pesan selama pandemi COVID-19 tidak ada seorang pun pengunjung yang melihat pementasan musik tradisional meski protokol kesehatan sudah diterapkan oleh pengelola wisata dengan memberikan tanda silang warna kuning untuk menjaga jarak pengunjung, namun yang nampak hanya kegiatan seorang laki-laki sedang membersihkan tempat tersebut.

Makna Konotasi dari pembacaan 6 prosedur tersebut bahwa pengunjung saat ini sedang sepi hanya kesunyian yang menyelimuti akibat dampak pandemi COVID-19. Mitos yang terbangun dalam foto tersebut mengenai bagaimana kondisi saat ini di tempat wisata pertunjukan seni budaya tradisional Saung Angklung Udjo di kota Bandung, Jawa Barat. Akibat pandemi COVID-19 yang sudah satu tahun melanda Indonesia memberikan dampak pada sepinya pengunjung dengan deretan tempat duduk yang kosong meski sudah memberlakukan protokol kesehatan oleh pengelola wisata.Sementara aktivitas yang dilakukan oleh pekerja seperti membersihkan tempat pementasan masih rutin dilakukan di mana biaya pengeluaran untuk kebersihan juga terus berjalan mengakibatkan pembengkakan biaya. 


\section{Analisis Data Foto 3}

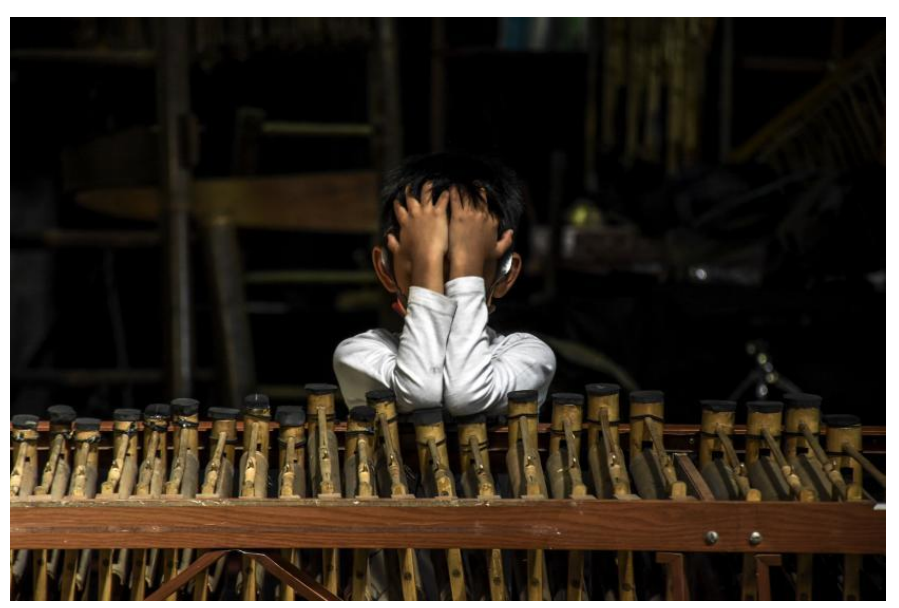

Gambar 3. Data foto 3 dalam akun Instagram @ republikafoto

Tatanan signifikasi pertama pada makna Denotasi tampak dalam foto tersebut memperlihatkan seorang anak laki-laki dengan menggunakan baju berwarna putih dan masker sedang menutupi kepala mukanya dengan kedua tangan di atas alat musik angklung. Latar belakang gelap memperlihatkan beberapa alat musik tradisional angklung lainnya.Tatanan signifikasi kedua makna Konotasi pada : a) Trick Effect menurut penulis tidak tampak dan tidak ditemukan adanya manipulasi foto. Editing atau penyuntingan foto yang tampak dilakukan hanya sebatas koreksi warna dan kecerahan saja dengan membuat latar belakang sedikit gelap sehingga kontras dengan objek utamanya yang lebih terang dan lebih menonjol. b) Pose foto tersebut termasuk ke dalam jenis foto portraits atau potret yang menampilkan wajah seseorang secara close up, mementingkan karakter dari objek yang di foto. Unsur utama yang diperhatikan dalam foto potret ini adalah kekhasan (ekspresi) wajah atau kekhasan lainnya dari objek yang difoto. Dilihat dari pose dan ekspresi muka seorang anak laki-laki yang menutupi kepala mukanya dengan kedua tangan dan posisi di atas alat musik angklung menggambarkan gesture non verbal yang dapat ditafsirkan sedang dalam keadaan emosi yang sedang sedih melihat kondisi pertunjukan musik tradisional angklung sepi tanpa pengunjung. Keadaan sepi ini ditunjang dari latar belakang yang dalam kondisi gelap cahanya dan sepi. c) Object utama yang ditampilkan menjadi Point Of Interest (POI) terlihat menonjol dan menarik mata memandang pada sebuah foto tersebut adalah seorang anak laki-laki yang sedang meletakkan siku tangannya di atas alat musik angklung dengan menutupi kepala mukanya. d) Photogenia menggunakan teknik pemotretan diantaranya lighting atau pencahayaan available light yang memanfaatkan sumber cahaya berasal dari cahaya matahari yang dipotret pada siang hari dengan arah cahaya datang dari depan (frontlight) objek yang membuat bagian depan objek tercahayai penuh sehingga terlihat perbedaan gradasi antara area yang gelap (shadow) pada latar belakang (background) objek dengan area terang (highlight) pada objek. Tingkat ketajaman gambar atau Depth Of Field (DOF) terlihat pada objek depan (foreground) yaitu fokus tajam alias tidak buram pada anak laki-laki dengan alat musik angklungnya. Sedangkan pada latar belakang (background) terliha buram atau disebut dengan efek bokeh. Hal ini dapat terjadi apabila menggunakan exposure bukaan diafragma (f) besar pada angka kecil bekisar f/1.4 hingga f/5.6 dan ASA/ISO bekisar ISO 100 atau 200 dengan shutter speed tinggi untuk mendapatkan efek freezing atau tidak bergerak pada objeknya. Posisi pemotretan mengambil sudut pandang straight angleleye level yaitu sudut pengambilan sejajar dengan tinggi objeknya yang umum digunakan memberikan kesan gambaran keadaan objek yang sesungguhnya. e) Aestheticism yang diambil dengan format 
horizontal tampak menarik menampilkan anak laki-laki yang sedang duduk menutupi kepala mukanya di depannya ada sebuah alat musik sebagai pelengkap fotonya dengan latar belakang blur atau buram. Elemen-elemen yang diambil dan disusun sedemikian rupa menggunakan komposisi simetris vertikal merupakan teknik pembagian bidang rata kanan dan kiri secara seimbang yang ditarik secara garis vertikal dari atas ke bawah objek dengan menempatkan objek seorang anak laki-laki di tengah frame. Komposisi ini menimbulkan kesan pembatasan formal, statis dan membosankan yang dialami oleh objek akibat pandemi COVID-19. f) Syntax dalam foto tersebut adalah seorang anak mengikuti kegiatan belajar alat musik angklung. Sintaksis ini tersirat menimbulkan makna pandemi COVID19 membuat kegiatan belajar alat musik angklung di Saung Angklung Udjo yang diikuti seorang anak sudah tidak seperti biasanya lagi yang ramai dan riang gembira karena adanya pembatasan yang memaksa semua orang harus tinggal di rumah membuat aktivitas kegiatan belajar alat musik angklung menjadi sepi.

Setelah melalui pembacaan 6 prosedur tersebut, makna Konotasi memperlihatkan bahwa pandemi COVID-19 membuat seorang anak juga ikut merasakan sebenarnya akan dampak yang terjadi di tempat wisata pertunjukan seni budaya Saung Angklung Udjo di mana dalam mengikuti kegiatan belajar alat musik Angklung tidak seramai sebelum pandemi. Mitos yang terbangun dalam foto tersebut bahwa pandemi COVID-19 dampaknya tidak hanya dirasakan oleh manusia dewasa namun juga oleh anak-anak yang belajar alat musik tradisional di Saung Angklung Udjo.Pembatasan yang dilakukan dengan protokol kesehatan ketat saat pandemi COVID-19 tidak menjadikan masyarakat mau berkunjung namun lebih lebih banyak memilih tinggal di rumah untuk menghindari tertular penyakit ini.

\section{Analisis Data Foto 4}

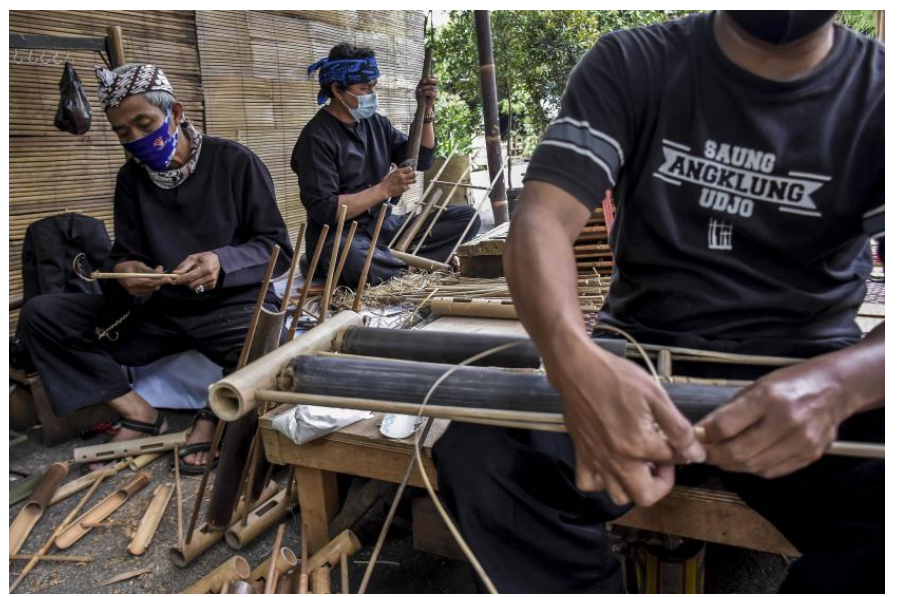

Gambar 4. Data foto 4 dalam akun Instagram @ republikafoto

Tatanan signifikasi pertama pada makna Denotasi tampak dalam foto tersebut terlihat beberapa orang laki-laki dengan mengenakan kaos hitam bertuliskan Saung Angklung Udjo dan celana hitam. Sebagian lagi mengenakan pakaian adat Sunda yakni baju dan celana Pangsi berwarna hitam dengan menggunakan ikat kepala khas Sunda atau Iket Sunda serta menggunakan masker sedang menyelesaikan pekerjaan membuat alat musik angklung. Tatanan signifikasi kedua makna Konotasi pada a) Trick Effect berlebihan pada foto tersebut tidak tampak dan tidak ditemukan adanya manipulasi foto yang dapat merubah esensi foto jurnalistik yang apa adanya fakta untuk diberitakan. b) Pose pada foto tersebut termasuk ke dalam jenis foto human interest atau daily life photo di mana dalam foto tersebut menunjukkan bagaimana kehidupan para pekerja di Saung Angklung Udjo 
yang membuat beberapa alat musik Angklung di saat pandemi COVID-19 sedang berlangsung. c) Object yang ditampilkan menjadi point of interest (POI) terlihat menonjol dan menarik pada beberapa orang laki-laki dengan mengenakan pakaian khas Sunda sedang membuat alat musik Angklung di masa pandemi COVID-19 dengan tetap menggunakan masker.d) Photogenia menggunakan teknik pemotretan dengan lighting atau pencahayaan available light yang memanfaatkan sumber cahaya berasal dari cahaya matahari yang dipotret di ruang terbuka (outdoor) pada siang hari. Tingkat ketajaman gambar atau Depth OfField (DOF) terlihat fokus pada objek belakang (background) kedua pekerja yang menggunakan pakaian khas Sunda lengkap dengan masker, sedangkan pada objek depan (foreground) kaos hitam bertuliskan Saung Angklung Udjo terlihat kurang fokus atau blur. Untuk mendapatkan background tajam menggunakan pengaturan exposure bukaan diafragma (f) kecil pada angka besar bekisar f/8 hingga f/22 dan ASA/ISO rendah berkisar ISO 100 atau 200 dengan shutter speed di 1/80 atau 1/100 agar foto tidak blur karena kamera goyang. Posisi pemotretan mengambil sudut pandang straight angleleye level yaitu sudut pengambilan sejajar dengan tinggi objeknya yang umum digunakan memberikan kesan gambaran keadaan objek yang sebenarnya. e) Aestheticismfoto diambil dengan format horizontal tampak menarik menampilkan pekerja di Saung Angklung Udjo yang sedang mengerjakan pekerjaan membuat alat musik angklung. Elemen-elemen disusun sedemikian rupa menggunakan komposisi Rule of Third di mana fotografer membagi bidang foto menjadi sembilan kotak yang sama besar dan proporsional. Aturan sepertiga bidang tersebut terdapat empat titik yang kemudian fotografer meletakkan POI atau objek utamanya pada salah satu titik tersebut. Komposisi ini menimbulkan kesan proporsional yang dilakukan para pekerja Saung Angklung Udjo yang tetap memproduksi alat musik tradisional angklung dengan protokol kesehatan meski di masa pandemi COVID-19.f) Syntax pada foto tersebut yaitu pekerja menyelesaikan pembuatan angklung di Saung Angklung Udjo, tempat wisata pertunjukan seni budaya tradisional di Kota Bandung, Jawa Barat. Sintaksis ini menimbulkan makna pandemi COVID-19 tidak menghalangi para pekerja untuk menyelesaikan pembuatan alat musik angklung dengan tetap menggunakan atribut khas Sunda di tempat wisata Saung Angklung Udjo dan tetap mengikuti protokol kesehatan. Meski dampak pandemi COVID-19 telah membuat sebagian besar para pekerja yang dirumahkan.

Makna Konotasi hasil 6 prosedur tersebut bahwa di masa pandemi COVID-19 ini sebagian pekerja di Saung Angklung Udjo masih tetap semangat untuk memproduksi alat musik angklung dengan menggunakan protokol kesehatan meskipun sebagian besar pekerja lainnya dirumahkan. Mitos yang terbangun dalam foto tersebut bahwa dampak pandemi COVID-19 tidak hanya mempengaruhi pendapatan para pekerja dengan sepinya pesanan alat musik angklung akibat sepinya pengunjung, namun juga aktivitas yang dilakukan oleh sebagian pekerja yang masih bekerja di Saung Angklung Udjo. Para pekerja tetap bekerja seperti biasanya membuat alat musik angklung, namun dengan tetap menerapkan protokol kesehatan yaitu memakai masker dan menjaga jarak. 


\section{Analisis Data Foto 5}

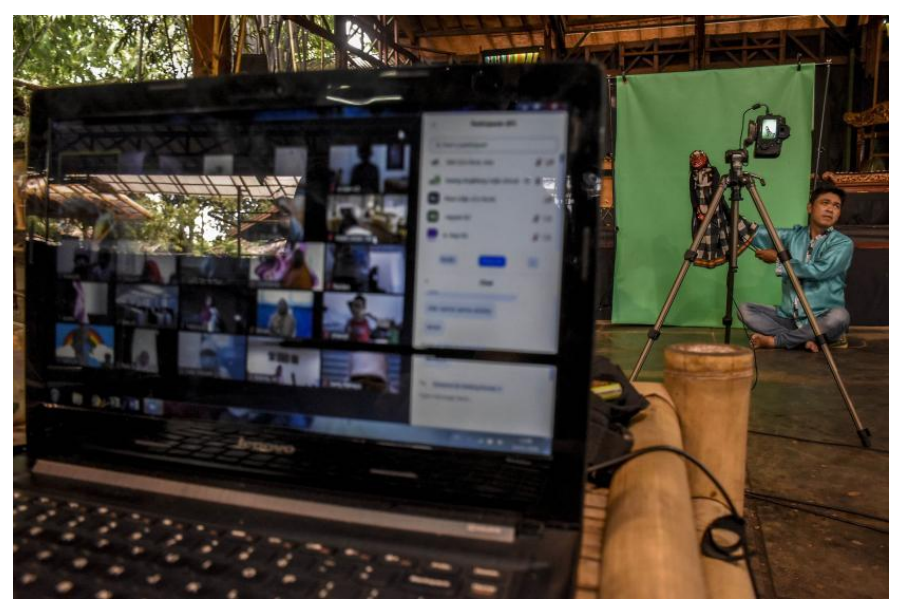

\section{Gambar 5. Data foto 5 dalam akun Instagram @ republikafoto}

Tatanan signifikasi pertama pada makna Denotasi tampak dalam foto tersebut memperlihatkan seorang laki-laki duduk bersila sedang memainkan wayang golek atau boneka kayu khas Sunda. Di belakangnya ada background green screen atau layar hijau. Sedangkan di depannya ada kamera dan tripod serta laptop nyala bergambar orang-orang menggunakan plaform virtual zoom meeting. Tatanan signifikasi kedua makna Konotasi pada a) Trick Effect tidak ada manipulasi foto berlebihan yang dilakukan oleh fotografer untuk menjadikan foto tersebut menjadi lebih bagus atau artistik, karena foto jurnalistik tidak memperbolehkan adanya manipulasi foto yang dapat mengubah esensi dari sebuah foto. Hanya menambah kecerahan warna atau menggelapkannya yang dilakukan oleh fotografer untuk mendapatkan gradasi gelap terang pada fotonya. b) Pose foto tersebut termasuk ke dalam jenis. foto human interest atau daily life photo di mana dalam foto tersebut menunjukkan bagaimana pose atau gaya dan ekspresi pekerja di Saung Angklung Udjo saat sedang melakukan pementasan wayang golek secara virtual dengan menggunakan platform zoom meeting di saat pandemi COVID-19 sedang berlangsung. c) Object Point Of Interest (POI) sebagai objek utama adalah seorang laki-laki duduk bersila yang sedang membawakan wayang golek dengan kamera dan tripod di depannya. d) Photogenia teknik pemotretan yang diambil dengan lighting atau pencahayaan artificial light yang memanfaatkan sumber cahaya buatan berasal dari cahaya lampu dari arah samping kanan objek atau sidelight yang dipotret di ruang tertutup (indoor) pada siang hari. Tingkat ketajaman gambar atau Depth OfField (DOF) terlihat fokusnya pada objek belakang (background) laki-laki bersila yang membawakan wayang golek, sedangkan pada objek depan (foreground) berupa laptop yang fokusnya tidak tajam atau blur. Pengaturan exposure yang dilakukan oleh fotografer pada bukaan diafragma (f) besar pada angka kecil bekisar f/1.4 hingga f/5.6 dan ASA/ISO tinggi bekisar ISO 400 atau 800 dengan shutter speed tengah-tengah di $1 / 60$ atau 1/80. Posisi pemotretan mengambil sudut pandang straight angleleye level yaitu sudut pengambilan sejajar dengan tinggi objeknya memberikan kesan gambaran keadaan objek yang sebenarnya. e) Aestheticismfoto diambil dengan format horizontal tampak menarik yang menampilkan pekerja di Saung Angklung Udjo sedang melakukan pementasan wayang golek secara virtual. Elemen-elemen disusun sedemikian rupa dalam satu bingkai komposisi Golden Ratioatau yang dikenal dengan golden section di mana point of interest-nya berada pada titik persimpangan dua garis horisontal yang memiliki perbandingan 1:1,6 atau 38/62. Komposisi ini menimbulkan kesan satu kesatuan antar elemen memiliki kekuatan atau energi yang saling terhubung 
atau terkait membentuk keselarasan seperti alam. Dampak pandemi COVID-19 memberikan energi atau kekuatan bagi pekerja di Saung Angklung Udjo untuk tetap bertahan dengan melakukan inovasi pertunjukan yang sebelumnnya offline menjadi virtual yang terkoneksi melalui media digital. f) Syntax pada foto tersebut bisa dilihat dalam caption fotonya yaitu karyawan Saung Angklung Udjo melakukan pementasan secara virtual melalui sosial media. Sintaksis ini menimbulkan makna untuk tetap bertahan di masa pandemi COVID-19, kegiatan pertunjukan musik tradisional di Saung Angklung Udjo yang awalnya pekerja mementaskan di depan pengunjung secara langsung di lokasi tempat pementasan berubah menjadi pertunjukan secara virtual atau online dengan bantuan media digital berupa alat perekam kamera, tripod, laptop, aplikasi zoom meeting dan koneksi internet agar dapat ditonton oleh pengunjung online.

Makna Konotasi yang dihasilkan dari tahapan 6 prosedur tersebut yakni bagaimana kondisi sebenarnya dampak pandemi COVID-19 yang telah merubah kegiatan pertunjukan seni budaya musik tradisional wisata Saung Angklung Udjo ini menjadi wisata pementasan secara virtual menggunakan platform media digital yakni zoom meeting agar tetap dapat bertahan dan tetap eksis meski secara ekonomi belum bisa menutupi biaya pengeluaran yang cukup tinggi. Mitos yang terbangun dalam foto tersebut tentang kejadian pandemi COVID-19 yang sudah berlangsung selama 1 tahun di Indonesia ini memberikan dampak yang signifikan bagi tempat wisata yang mengandalkan pengunjung sebagai pemasukan utamanya. Namun, agar tetap bertahan tempat wisata Saung Angklung Udjo berinovasi dengan membuat wisata virtual Saung Angklung Udjo menggunakan platform digital kekinian.

\section{Analisis Data Foto 6}

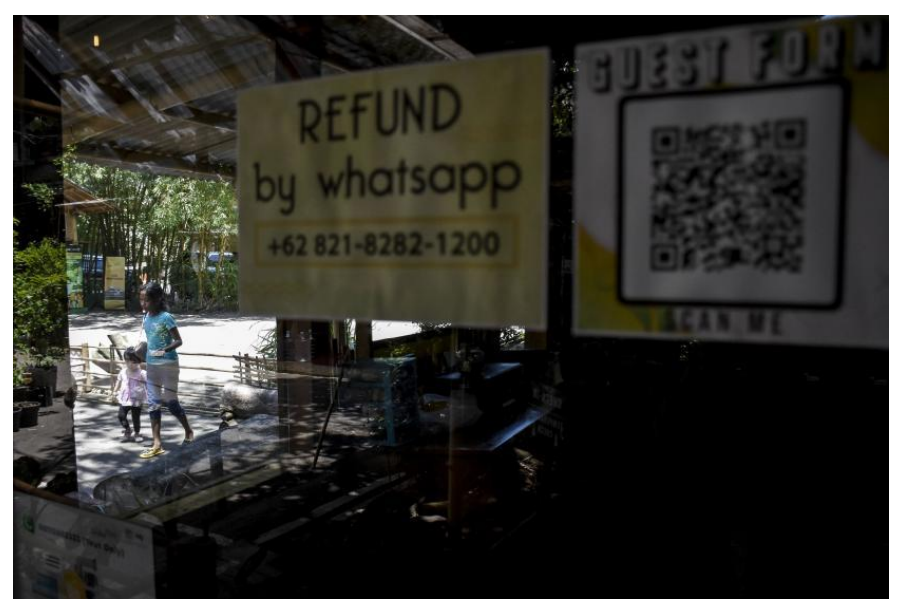

Gambar 6. Data foto 6 dalam akun Instagram @ republikafoto

Tatanan signifikasi pertama pada makna Denotasi memperlihatkan dua buah poster yang dipasang dan ditempelkan di kaca.Poster berwarna kuning bertuliskan REFUND by whatsapp +62 821-8282-1200, dan poster yang satunya bertuliskan GUEST FORM (ada kode barcode) SCAN ME. Ada dua orang anak sedang berjalan melintas di depan (akibat pantulan kaca) atau di samping kanan letak poster tersebut. Tatanan signifikasi kedua makna Konotasi pada : a) Trick Effect tidak ada unsur manipulasi foto yang dapat merubah esensi dari foto jurnalistik yang dihasilkan. b) Pose foto tersebut termasuk ke dalam jenis. fotodaily life photo atau human interest di mana dalam foto tersebut menunjukkan bagaimana pose atau gaya dan ekspresi. Foto tersebut menunjukkan adanya pose atau gaya dan ekspresi pada objek utamanya yakni dua orang anak yang sedang melintas. Sedangkan 
posisi poster dipasang dan ditempel dikaca menandakan sebuah informasi loket pertunjukan seni budaya tradisional di tempat wisata Saung Angklung Udjo. c) Object point of interest (POI) adalah sebuah poster yang mencantumkan nomor WhatsApp dan barcode scan. Sedangkan objek pendukung merupakan dua orang anak yang sedang lewat di sana. d) Photogenia teknik pemotretan yang diambil dengan lighting atau pencahayaan available light yang memanfaatkan sumber cahaya berasal dari cahaya matahari yang dipotret di ruang terbuka (outdoor) pada siang hari. Tingkat ketajaman gambar atau Depth Of Field (DOF) pada objek belakang (background) dua orang anak perempuan yang sedang melintas terlihat fokus dan luas kedalaman ruang tajamnya. Sedangkan pada objek depan (foreground) berupa dua poster informasi dibuat tidak tajam atau blur. Pengaturan exposure yang dilakukan oleh fotografer menurut peneliti pada bukaan diafragma (f) kecil pada angka besar bekisar f/8 hingga f/22 dan ASA/ISO rendah bekisar ISO 100 atau 200 dengan shutter speed di 1/80 atau 1/100. Posisi pemotretan mengambil sudut pandang straight angleleye level yaitu sudut pengambilan sejajar dengan tinggi objek utamanya yakni dua orang anak perempuan memberikan kesan gambaran keadaan objek yang sebenarnya. e) Aestheticism foto yang diambil dengan format horizontal tampak menarik yang menampilkan dua orang sedang melintas jelas fokusnya dan dua poster berisi nomor Whatsapp dan barcode scan yang dibuat sedikit blur atau tidak fokus. Elemen-elemen yang disusun sedemikian rupa dalam satu bingkai komposisi Golden Ratio atau yang dikenal dengan golden sectiondi mana point of interest-nya berada pada titik persimpangan dua garis horisontal yang memiliki perbandingan 1:1,6 atau 38/62. Komposisi ini menimbulkan kesan satu kesatuan antar elemen yang memiliki kekuatan atau energi yang saling terhubung atau terkait membentuk keselarasan alam.Pengunjung di Saung Angklung Udjo seakan memberikan energi atau kekuatan terhadap hidup matinya tempat wisata pertunjukan seni budaya tradional musik Angklung pada masa pandemi COVID-19. f). Syntax foto tersebut adalah dua orang anak melintas di depan loket pembelian tiket yang tampak sepi di Saung Angklung Udjo, tempat wisata pertunjukan seni budaya tradional di Kota Bandung, Jawa Barat. Sintaksis ini menimbulkan makna pandemi COVID-19 memberikan dampak sepinya pengunjung yang membeli tiket di loket pembelian tiket.

Makna Konotasi pada 6 prosedur pembacaan tersebut memperlihatkan sebuah bentuk rangkaian pesan bahwa sepinya pengunjung di loket pembelian tiket pertunjukan akibat dampak yang ditimbulkan oleh pandemi COVID-19 yang masih berlangsung. Mitos yang terbangun dalam foto tersebut memiliki tafsir dan makna tentang kejadian pandemi COVID-19 yang sudah berlangsung selama 1 tahun di Indonesia ini memberikan dampak yang berat bagi tempat wisata yang mengandalkan pengunjung sebagai pemasukan utamanya. Dampak ini terlihat pada foto tersebut dengan semakin sepinya pengunjung yang datang di loket pembelian tiket lokasi wisata sehingga mengakibatkan berkurangnya pemasukan dan terus bertambahnya pengeluaran.

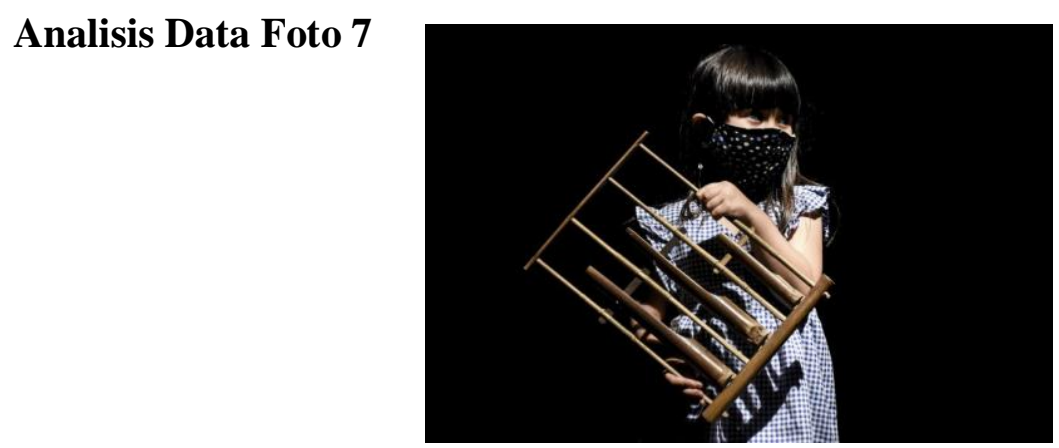

Gambar 7. Data foto 7 dalam akun Instagram @ republikafoto 
Tatanan signifikasi pertama pada makna Denotasi memperlihatkan seorang anak perempuan berlatar belakang gelap sedang memegang angklung dengan memakai masker di wajahnya. Memakai baju kotak-kotak kecil putih biru, dan masker hitam berbintikbintik. Tatapan matanya melihat ke arah sebelah kirinya. Tatanan signifikasi kedua makna Konotasi pada a) Trick Effect foto tersebut tidak ditemukan adanya manipulasi foto. b) Pose foto tersebut termasuk ke dalam jenis foto portraits atau potret yang menampilkan wajah seseorang secara close up, mementingkan karakter dari objek yang difoto. Unsur utama yang diperhatikan dalam foto potret ini adalah kekhasan (ekspresi) wajah dari objek yang difoto. Dilihat dari pose dan ekspresi muka seorang anak perempuan yang memakai masker dan memegang alat musik angklung dengan tatapan matanya ke arah sebelah kirinya menggambarkan gesture sedang dalam keadaan membayangkan suatu kejadian yang mungkin terjadi. c) Object yang ditampilkan menjadi point of interest (POI) terlihat seorang anak perempuan sedang memegang angklung dan menggunakan masker dengan wajah yang kurang bahagia karena dampak pandemi COVID-19. d) Photogenia diambil dengan teknik pemotretan diantaranya lighting atau pencahayaan available light yang memanfaatkan sumber cahaya berasal dari cahaya matahari yang objeknya dipotret pada siang hari dengan arah cahaya datang dari arah samping (side lighting) objek yang membuat bagian samping dan depan objek di beri cahaya penuh sehingga terlihat perbedaan gradasi antara area yang gelap (shadow) pada latar belakang (background) objek dengan area terang (highlight) pada objek. Tingkat ketajaman gambar atau Depth Of Field (DOF) terlihat pada objek depan (foreground) yaitu fokus tajam alias tidak buram pada anak perempuan dengan memegang alat musik angklungnya. Sedangkan pada latar belakang (background) terlihat gelap. Hal ini dapat terjadi apabila menggunakan pengaturan exposure bukaan diafragma (f) kecil pada angka besar bekisar f/8 hingga f/22 dan ASA/ISO bekisar ISO 100 atau 200 dengan shutter speed tinggi untuk mendapatkan efek freezing atau tidak bergerak pada objeknya. Posisi pemotretan mengambil sudut pandang straight angle/ eye level yaitu sudut pengambilan sejajar dengan tinggi objeknya yang umum digunakan memberikan kesan gambaran keadaan objek yang sesungguhnya. e) Aestheticism foto menggunakan format horizontal tampak menarik menampilkan anak perempuan yang sedang memegang alat musik tradisonal angklung dengan latar belakang gelap. Elemen-elemen yang diambil dan disusun sedemikian rupa menggunakan komposisi dead center merupakan teknik menempatkan objek foto atau POI tepat di tengah frame foto. Komposisi ini menimbulkan kesan membuat objek foto lebih stand out/ menonjol dan ditunjang dengan background warna gelap. f) Syntax dalam foto tersebut adalah seorang anak memegang alat musik angklung di Saung Angklung Udjo, tempat wisata pertunjukan seni budaya tradisional di Kota Bandung, Jawa Barat. Menimbulkan makna bahwa pandemi COVID-19 membuat pengunjung pertunjukan seni budaya tradisional tetap wajib menerapkan protokol kesehatan.

Makna Konotasi dari 6 prosedur pembacaan tersebut bahwa pandemi COVID-19 membuat seorang anak membayangkan saat mengenakan masker sambil memegang alat musik tradisional angklung akan sepinya pengunjung. Mitos yang terbangun dalam foto tersebut bagaimana permainan angklung mulai tidak lagi terdengar ditelinganya dan sorak ramai pengunjung serta permainan pentas seni tidak lagi tercermin di wajah seorang anak perempuan, sehingga terlihat kehilangan semangat pada saat memegang angklung. 


\section{Analisis Data Foto 8}

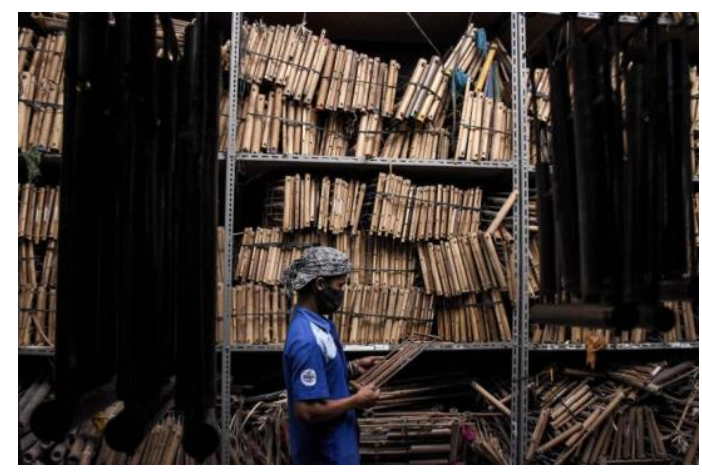

\section{Gambar 8. Data foto 8 dalam akun Instagram @republikafoto}

Tatanan signifikasi pertama pada makna Denotasi memperlihatkan seorang karyawan berbaju biru memakai ikat kepala khas Sunda atau Iket Sunda dan mengenakan masker sedang memegang angklung dengan latar belakang (backdground) tumpukan ratusan angklung yang tertata rapi dalam tiga susunan dan terikat. Sementara latar depan (foreground) terlihat siluet angklung yang menggantung. Tatanan signifikasi kedua makna Konotasi pada a) Trick Effect tidak ditemukan adanya manipulasi foto. b) Pose foto tersebut termasuk ke dalam jenis foto human interest atau daily life photo di mana dalam foto tersebut menunjukkan kehidupan pekerja di Saung Angklung Udjo yang sedang melakukan pemeliharaan dengan memeriksa satu persatu angklung dari ratusan alat musik Angklung yang tidak terpakai namun tertata rapi dalam rak tiga susun di saat pandemi COVID-19 sedang berlangsung. c) Object yang ditampilkan menjadi point of interest (POI) terlihat pekerja Saung Angklung Udjo dengan background ratusan alat musik tradisional angklung yang tidak terpakai namun tertata rapi dalam rak 3 susun. d) Photogenia diambil menggunakan teknik pemotretan dengan lighting atau pencahayaan available light yang memanfaatkan sumber cahaya berasal dari cahaya matahari yang dipotret di ruang terbuka (outdoor) pada siang hari. Tingkat ketajaman gambar atau Depth Of Field (DOF) terlihat fokus pada objek pekerja yang menggunakan ikat kepala khas Sunda dengan masker dan latar belakang (background) tumpukan ratusan angklung yang tidak terpakai. Sedangkan pada objek depan (foreground) siluet angklung yang terlihat blur atau kurang fokus. Background dibuat tajam di ruang terbuka (outdoor) oleh fotografernya dengan menggunakan pengaturan exposure bukaan diafragma (f) kecil pada angka besar bekisar f/8 hingga f/22 dan ASA/ISO rendah bekisar ISO 100 atau 200 dengan shutter speed di 1/80 atau 1/100 agar objek foto tidak blur karena kamera goyang. Posisi pemotretan mengambil sudut pandang low angle yaitu sudut pengambilan pada posisi di bawahnya atau lebih rendah daripada objek foto memberikan kesan gambaran objek yang terlihat dominan, tangguh, besar, dan elegan. e). Aestheticism foto menggunakan format horizontal tampak menarik menampilkan seorang karyawan Saung Angklung Udjo yang sedang melakukan pemeriksaan alat musik tradisonal angklung dari ratusan angklung yang tidak terpakai akibat pandemi COVID-19 yang dibingkai latar depan siluet angklung. Elemen-elemen yang diambil dan disusun sedemikian rupa menggunakan komposisi framing merupakan teknik menempatkan objek utama foto atau Point of Interest (POI) yang diberi bingkai objek lain sebagai latar depan (foreground) dengan tujuan untuk mengarahkan pandangan / perhatian orang menuju ke arah subjek utama yang ada di dalam bingkai tersebut. Komposisi ini menimbulkan kesan mengarahkan perhatian orang menuju ke arah objek utama yang berada di dalam bingkai tersebut. f) Syntax terdapat dalam 
caption foto adalah seorang karyawan membersihkan alat musik angklung di Saung Angklung Udjo, tempat wisata pertunjukan seni budaya tradisional di Kota Bandung, Jawa Barat. Tersirat makna bahwa dampak pandemi COVID-19 tidak hanya sepi pengunjung namun juga mengakibatkan ratusan alat musik angklung yang biasanya selalu digunakan untuk pementasan menjadi terbengkalai tidak terawat sehingga memerlukan biaya perawatan tambahan untuk pemeliharaanya.

Hasil 6 prosedur pembacaan foto tersebut didapatkan makna Konotasi bahwa fotografer berusaha menunjukkan sebesar apa dampak COVID-19 bagi wisata pertunjukan seni budaya tradisional Saung Angklung Udjo di Bandung yang terkenal tidak hanya dalam negeri namun juga sampai manca negara. Karena dalam visual fotonya nampak jelas ratusan angklung 'terparkir' tidak digunakan yang membutuhkan ekstra perawatan selama pandemi COVID-19 berlangsung. Mitos yang terbangun dalam foto tersebut 1 tahun pandemi COVID-19 di Indonesia memberikan dampak yang memprihatinkan dengan banyaknya alat musik tradisional angklung terikat dan tertata rapi dalam rak 3 susun menandakan tidak adanya kegiatan alunan musik tradisional akibat tidak adanya pengunjung yang berkunjung ke tempat wisata tersebut.

\section{E. Kesimpulan}

Foto jurnalistik mampu merepresentasikan dampak ekonomi akibat pandemi COVID-19 yang sudah berlangsung selama kurun waktu satu tahun ini, sebagaimana yang terjadi di tempat wisata pertunjukan seni budaya tradisional Saung Angklung Udjo, kota Bandung, Jawa Barat. Pembacaan dari delapan foto jurnalistik pada tatanan signifikasi pertama secara makna Denotasi dampak ekonomi yang direpresentasikan adalah sepinya pengunjung meski pengelola tempat wisata sudah memberlakukan protokol kesehatan baik di area wisata dengan menjaga jarak dan menggunakan masker. Tatanan signifikasi kedua secara makna Konotasi menggambarkan kesunyian pertunjukan musik tradisional angklung di tempat wisata Saung Angklung Udjo, Kota Bandung, Jawa Barat. Kebijakan pemerintah yang memberlakukan Pembatasan Sosial Berskala Besar (PSBB) dan Pemberlakuan Pembatasan Kegiatan Masyarakat (PPKM) berbasis mikro selama pandemi COVID-19 yang mengharuskan masyarakat untuk tinggal di rumah membuat wisata pertunjukan ini seakan mati suri. Secara Mitos dampak ekonomi yang ditimbulkan selama pandemi COVID-19 dalam satu tahun ini menjadi kenyataan tidak hanya membuat pendapatan menurun drastis namun juga mengakibatkan para pekerja banyak yang "dirumahkan". Untuk bisa tetap bertahan, bentuk resiliensi yang dilakukan pihak pengelola wisata Saung Angklung Udjo ini dengan melakukan inovasi wisata virtual edukasi seni budaya khas Saung Angklung Udjo meskipun tetap tidak bisa mengangkat minat pengunjung mendaftar wisata kekinian ini dengan menggunakan platform digital zoom meeting.

\section{DaftarPustaka}

Ajidarma, Seno Gumira. (2016). Kisah Mata Fotografi antara Dua Subjek: Perbincangan tentang Ada. Yogyakarta: Galang Press.

andi.link. (2020). Hootsuite (We are Social): Indonesian Digital Report 2020. Retrieved 17 Maret, 2021, from https://andi.link/hootsuite-we-are-social-indonesian-digital-report-2020/

Budiman, Kris. (2003). Semiotika Visual. Yogyakarta: LKIS.

Burhanuddin. (2014). Fotografi. Yogyakarta: Graha Ilmu.

cnnindonesia.com. (2021). SATU TAHUN CORONA DI INDONESIA

Wamenkes soal 1 Tahun Pandemi: Tiada yang Tahu Kapan Berakhir. Retrieved 17 Maret, 2021, from https://www.cnnindonesia.com/nasional/20210302131452-20-612634/wamenkes-soal1-tahun-pandemi-tiada-yang-tahu-kapan-berakhir 
e-journal.uajy. (2021). Sejarah dan Perkembangan Fotografi. Retrieved 17 Maret, 2021, from http://e-journal.uajy.ac.id/179/3/2TA13124.pdf

Fiske, John. (2016). Pengantar Ilmu Komunikasi. Yogyakarta: Buku Litera.

Geographic, National. (2020). Photo of COVID-19 victim in Indonesia sparks fascination-and denial. $\quad$ Retrieved 17 Maret, 2021, from https://www.nationalgeographic.com/photography/article/covid-victim-photograph-sparksfascination-and-denial-indonesia

Hopkins, Johns. (2021). Coronavirus COVID-19 Global Cases by Johns Hopkins CSSE. Retrieved 17 Maret, 2021, from https://gisanddata.maps.arcgis.com/apps/opsdashboard/index.html\#/bda7594740fd40299423 $\underline{467 \mathrm{~b} 48 \mathrm{e} 9 \mathrm{ecf} 6}$

KBBI. (2016). Fotografi. Kamus Besar Bahasa Indonesia Daring. Retrieved 17 Mei, 2021, from https://kbbi.kemdikbud.go.id/entri/fotografi

kompas.com. (2021). Satu Tahun Pandemi Covid-19 di Indonesia: Kilas Balik Kisah Pasien 01 dan 02. Retrieved 17 Maret, 2021, from https://nasional.kompas.com/read/2021/03/02/05300091/satu-tahun-pandemi-covid-19-diindonesia-kilas-balik-kisah-pasien-01-dan-02?page=all

kompas.id. (2021a). Membungkus Foto Pandemi sebagai Pengingat Diri. Retrieved 17 Maret, 2021, from https://www.kompas.id/baca/foto/2021/03/13/membungkus-foto-pandemisebagai-pengingat-diri/

kompas.id. (2021b). Mengelola Emosi Saat Memotret. Retrieved 17 Maret, 2021, from https://www.kompas.id/baca/foto/2021/03/16/mengelola-emosi-saat-memotret/

medcom.id. (2021). Satu Tahun Covid-19 di Indonesia: Konsisten Perangi Pandemi. Retrieved 17 Maret, 2021, from https://www.medcom.id/ekonomi/analisis/PNgYqE7k-satu-tahun-covid19-di-indonesia-konsisten-perangi-pandemi

Sobur, Alex. (2015). Analisi Teks Media Suatu Pengantar untuk Analisis Wacana, Analisi Semiotik, dan Analisis Framing. Bandung: PT Remaja Rosdakarya.

Syakura, Abdan. (2021). In Picture: Alunan Sunyi Musik Tradisi, REPUBLIKA.co.id. Retrieved from https://www.republika.co.id/berita/qp8lks375/alunan-sunyi-musik-tradisi

Wijaya, Taufan. (2018). Literasi Visual: Manfaat dan Muslihat Fotografi. Jakarta: PT Gramedia Pustaka Utama. 